which was given an excellent account of the Clyde islands. Contemporary with Macculloch was another observer to whom Scottish geology stands deeply indebted, Ami Boué. After taking his degree in Scotland Boué went to Paris, where for a time he employed himself in preparing his "Essai géologique sur 1'Écosse," which saw the light in the year 1820. A few native inquirers began to make their appearance during the closing years of the eighteenth and the early decades of the nineteenth century as pioneers in the investigation of the details of the local geology. First came David Ure, whose excellent " History of Rutherglen and East Kilbride," published in ${ }^{1783}$, stands out preeminent for the fulness and faithfulness of its descriptions. Afterwards came Andrew C. Ramsay. After referring to the work of John Craig in Lanarkshire, Montgomery in Renfrewshire, Prof. Thomas Thomson in Glasgow University, and James Bryce, Sir Archibald Geikie said that of all the influences which conspired to raise in Glasgow an interest in the geological history of the district he was disposed to give the foremost place to that of James Smith, of Jordanhill.

\section{THE WINNIPEG MEETING OF THE BRITISH ASSOCIATION.}

A CIRCULAR has been prepared containing information A. of interest to members of the British Association who propose to attend the meeting to be held in Winnipeg, Manitoba, Canada, in August next, under the presidency of Sir J. J. Thomson, F.R.S. A representative local executive committee and officers have been appointed to conduct the local arrangements, which will include some interesting excursions and facilities for a tour through the Western Provinces to the Pacific Coast. The weather conditions during the latter part of August and the beginning of September are favourable in the Western Provinces of Canada, whilst in Winnipeg, situated 760 feet above sealevel, the days are warm, though not oppressively hot, and the nights are invariably cool. On account of August being the busiest month of the year in bookings to America, no reduction on minimum steamship rates will be made to members of the association, but superior accommodation may be granted, on the return voyage, at the ordinary minimum rate. The journey to Winnipeg, the meeting, and return home will take about thirty-two days. There will be a western excursion from Winnipeg to Regina, Moose Jaw, Calgary, Edmonton, Vancouver, and Victoria, and return to Winnipeg; members who take part in this excursion will require ten more days, thus making a six weeks' visit. Special fares are expected to be in force on the Canadian railways, amounting probably to a single fare for the return journey, from Montreal to Winnipeg, provided the party numbers not less than fifty; as also from Winnipeg to Vancouver, or for any side-trip made by individual members. The estimated personal expenditure of each member attending the meeting from Great Britain is a minimum of about 381 ., and an average of about $65 l$. The additional expense of the western excursion will be about $25 l$. Any member of the association who contemplates an extensive journey of exploration or for other scientific purposes, fishing, hunting, \&c., is invited to communicate with the local secrefaries of the British Association, University of Manitoba, Winnipeg. Expert advice and assistance will be given to any group of members who propose to avail themselves of this opportunity. A list of hotels and lodgings will be issued by the Winnipeg executive officers, to whom application should be made, early in July.

Members who propose to attend the meeting should send in their names to Mr. H. C. Stewardson, assistant treasurer of the British Association, Burlington House, London, W. not later than May 3 $\mathrm{I}$, by which date members should, if possible, complete their arrangements with the steamship companies, as all the best accommodation on steamers sailing in Ausust is booked some months ahead. An illustrated handbook of preliminary information, issued by the Winnipeg executive committee, will be forwarded from the onice of the association on receipt of $2 \frac{1}{2} d$. for postage.

\section{MECHANICAL, FLIGHT. Present Position.}

THE recent records made by Messrs. Wright, Farman, Delagrange, and Bleriot, together with the gradual accumulation of testimony in favour of mechanical flight, have finally disabused both the public and experts of the notion that aviation is a dream.

Many engineers from time immemorial have tackled the subject without success, and there was every reason for the sceptical attitude which has prevailed until the last few years. It is now evident that mechanical flight was impossible before science and engineering skill in the nineteenth century had so perfected the heat engine that considerable power was obtainable with but little weight. The present improved aspect of affairs must not, however, blind us to the fact that much has yet to be done. The most successful machines now in existence show serious defects, cannot be manipulated in troublesome weather, and have every part so light that at all times they are on the brink of collapsc. It rests with mechanical engineers to design a stronger machine without losing efficiency. In the course of this paper the author proposes to indicate certain points in which improvement is desired, and at the same time he has endeavoured to include a sufficiency of the theoretical and experimental knowledge available on the subject to enable a would-be aviator to construct a simple type of machine.

It cannot be too strongly realised that existing information is defective, and a few words as to research may be useful.

\section{Necessity for Research.}

It will be shown in the course of this paper that the whole question of mechanical flight depends upon a knowledge of the manner in which air reacts against solid bodies moving through it. A large number of researches have been made during the past 150 years, but even yet exact information is lacking on the majority of points.

Furthermore, mathematical analysis has not been sufliciently developed. A few great mathematicians (including Lords Kelvin and Rayleigh) have devoted some attention to the matter, but the author is not aware that any mathematician worthy of the name has considered it worth while to make an exhaustive study of the question, although it must be recognised that the recent advances in the theory of hydrodynamics form useful auxiliaries to the study of aërodynamics.

\section{Brief History of the Theory.}

The nature of fluid resistance has been investigated for many years, and the general principles are to be found in Newton's "Principia." The ballistic researches of Hutton and Robins at the end of the eighteenth century first clearly showed the quantitative value of air resistance, and their work is still valuable. On the hypothesis deducible from Newton's work, Messrs. Navier and GayLussac early in the nineteenth century formulated a theory of flight which showed that great power was necessary, and this notion held sway for many years after, so that little progress was made with the subject, flight being dcemed impracticable. Experiments by Wenham and Browning in the 'eighties, together with Langley's researches in America and Maxim's in England, clearly showed the fallacy of this idea. Pénaud in 1876 first gave the mathematical theory of the aëroplane, which had been conceived by Henson in 1840 . The late Mr. Froude, Lord Rayleigh, and Prof. Bryan developed this theory, and in I903 the last-named produced equations of stability for the aëroplane. Two years later Captain Ferber, of the French artillery, amplified these equations to find the conditions of lateral stability and the form of the trajectory, and quite recently $\mathrm{Mr}$. Lanchester has done similar work. Prof. Fitzgerald and Lord Rayleigh have given some attention to the ornithoptère, and Profs. Pettigrew and Marey at an earlier date arrived at several important conclusions respecting bird flight. The helicoptère has not received very much attention, but the cognate work of the late $\mathrm{Mr}$. Froude and his son on propellers has a most important 1 Ahridged from a naper y Mr. Herbert Chatley read before the Socie:y Engine $\epsilon$ rs on December 7, 1908 .

No. 2049, VOL. 79] 